\title{
Histological Effects of Alcoholic Extract of Cnidoscolus Aconitifolius on Bone Marrow Biopsy in Adult Male Wistar Rats
}

\author{
Odokuma Emmanuel Igho
}

Dept of Anatomy, Delta State University, Abraka, Nigeria

\begin{abstract}
Histological Effects Of Alcoholic Extract Of Cnidoscolus Aconitifolius On Bone Marrow Biopsy In Adult Male Wistar Rats.The present study was designed to investigate the effect of alcoholic extract of Cnidoscolus aconitifolius on bone marrow biopsy. The rats were acclimatized for two weeks, weighed and sorted into four groups (A - D) of three animals each with corresponding weights in the same group. Alcoholic extract of Cnidoscolus aconitifolius was administered orally to each animal in groups B - D at $200 \mathrm{ml} / \mathrm{kg}, 300 \mathrm{ml} / \mathrm{kg}$ and $500 \mathrm{ml} / \mathrm{kg}$ respectively. Group A was the control group and they fed with animal feed and water liberally. At the end of administration, animals were sacrificed and the bone marrow biopsy obtained from the xiphoid process of the sternum. This product was fixed in $10 \%$ formol saline and stained using hematoxylin and eosin. Results showed a marked dose dependent distortion of bone marrow histologic architecture.
\end{abstract}

Keywords Cnidoscolus Aconitifolius, Bone Marrow Aspirate, Rats

\section{Introduction}

Cnidoscolus aconitifolius has been used for both nutritional and medicinal import (Diaz - Bolio, 1975). Its shoots and leaves have been said to be a useful laxative, diuretic and circulation (Rowe, 1994).

Cnidoscolus aconitifolius is commonly called chaya or tree spinach. It is a perennial shrub of the family Euphorbiaceae commonly found in the tropics. It is one of the most productive green vegetables eaten in south western Nigeria where it is called Iyana Ipaja (Oyagbemi et al., 2008). It is also eaten by the inhabitants of south eastern Nigeria where it is called "Hospital too far" (Iwalewe et al., 2005).

Bone marrow is a large and a complex organ that is distributed throughout the cavities of skeleton. The total mass of bone marrow of an adult has been estimated to be 1600 $3700 \mathrm{~g}$ (Krause, 1981). It is seen in cavities of bones consist of a meshwork of vascular sinuses and highly branched fibroblast with interstices packed with haemopoietic cells (Barbara, 2006). It produces between the cells, plays a central role in the immune system being the site of B lymphocyte differentiation as well as containing large numbers of antibody secreting plasma cells. Bone marrow is of two types; Red marrow and Yellow marrow. Red marrows are active bone marrow crammed with dividing stem cells and the pre-

* Corresponding author:

secretfiles1800@yahoo.com (Odokuma Emmanuel Igho)

Published online at http://journal.sapub.org/medicine

Copyright (C) 2012 Scientific \& Academic Publishing. All Rights Reserved cursors of mature blood cells, this predominance of maturing erythrocytes conferring a deep red colour (Barbara, 2006).

With increasing age, the marrow of peripheral long bones becomes less active and it is progressively dominated by fat cells so that in mature mammals, much of the marrow is inactive and yellow in colour hence the name yellow bone marrow. The marrow fat content varies inversely with the quantity of haemopoieis tissue (De bruyn, 1981). The fat of yellow marrow is the last fat marrow in the body to be lost in starvation. When haemopoietic tissue is lost very rapidly it is replaced by interstitial mucin (gelatinous transformation) subsequently this mucin is replaced by fat cells (De bruyn, 1981).

Bone marrow produces blood cells by a process called haemopoiesis. The cells of blood are of three major functional classes: Red blood cells, White blood cells, Platelets (Barbara, 2006). The marrow is a continuous tissue, been capable of replenishing itself continually and therefore serves as an excellent measure of haemopoeitic function. Despite its properties, agents have been known to alter the normal morphology of the bone marrow to such an extent that it may overstimulation or in outright failure.

Studies have shown that the leaves contain components including protein $(5.7 \%)$, crude fiber $(1.9 \%)$, calcium (199.4mg / 100g), potassium $(217.2 \mathrm{mg} / 100 \mathrm{~g})$, iron (11.4mg / 100g), vitamin c (164.7mg / 100g) and carotene $(0.85 \mathrm{mg} / 100 \mathrm{~g})$ (Munsel et al., 1949; Martin and Ruberte, 1978).

It has been demonstrated to contain $27-42 \mathrm{mg}$ of hydrocyanide (Kolterman et al., 1984). According to this re- 
search, uncooked leaves of C. aconitifolius contain cyanogenic glycoside that produces hydrogen cyanide invivo. Numerous flavonoid compounds have been isolated from C. aconitifolius and most are kaempferol and quercetin glycosides (Kolterman et al., 1984).

The high fiber content and antibacterial activities of this plant have also been reported (Awoyinka et al., 2007). Apart from its antibacterial activities, observations on its function as a circulation stimulant has also been previously extensively studied (Rowe, 1994)

This present research was aimed at determining the effect of the plant on the bone marrow, bone marrow toxicity, and if it assist in haemopoiesis.

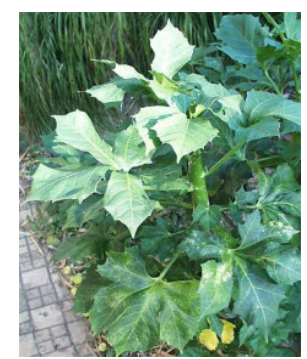

Figure 1. Showing an illustration of C. aconitifolius plant (Euphorbiaceae)

\section{Materials and Methods}

Approval for this study was obtained from department of anatomy ethic committee with Ref no. DELSU/BMS/ANA/ ERC/10/11/02.

Twelve adult male wistar rats weighing $140 \mathrm{~g}-185 \mathrm{~g}$ bred in animal house of Delta State University Abraka were used for this study. Animals were acclimatized for two weeks, weighed and sorted into four groups (A - D) with 3 rats per group. Alcoholic extract of C. aconitifolius was administered orally using a needle and a cannula for a period of fourteen days.

Group A served as the control and was administered $0.15 \mathrm{ml}$ of extract, feed and water ad libithium. Group B, C and D were administered $200 \mathrm{ml} / \mathrm{kg}, 300 \mathrm{ml} / \mathrm{kg}$, and $500 \mathrm{ml} / \mathrm{kg}$ of the extract respectively with feed and water freely.

At the end of administration, animals were euthanized using chloroform, sacrificed and the bone marrow was collected the xiphoid process of the sternum because after fetal life, only the marrow of the vertebrae, sternum, skull, pelvis and proximal femur is haemopoietic. Tissue was fixed in $10 \%$ formol saline this is to prevent autolysis and putrefaction (Drury et al., 1967). After fixing, tissue was placed in a decalcifying fluid (Drury et al., 1967).. and stained using haematoxylin \& eosin stain. Pictures of bone marrow stained slides were captured using were using digital microscopic eyepiece " SCOPETEK" DCM 500, 5.0 mega pixel connected to USB 2.0 computer (Barker et al., 1998).

\section{Results}

\section{Body Weight of Rats}

This is illustrated in the table below.

Table 1. showing the mean weight of rats before and after administration

\begin{tabular}{|c|c|c|c|}
\hline Groups & \multicolumn{2}{|l|}{$\begin{array}{c}\text { Body weight } \\
(\mathrm{g})\end{array}$} & \multicolumn{2}{l|}{} \\
\hline & $\begin{array}{c}\text { Initial in- } \\
\text { crease }\end{array}$ & Final increase & $\%$ increase \\
\hline A (control) & $140 \pm 4.08$ & $\mathrm{I} 60 \pm 4.08$ & 14.29 \\
\hline B & $158 \pm 10.28$ & $180 \pm 17.32$ & 20.25 \\
\hline C & $172 \pm 6.24$ & $215 \pm 6.45$ & 25 \\
\hline D & $185 \pm 10.08$ & $255 \pm 21.60$ & 37.83 \\
\hline
\end{tabular}

Microscopic Examination Of Bone Marrow Biopsy GROUP A (Control)

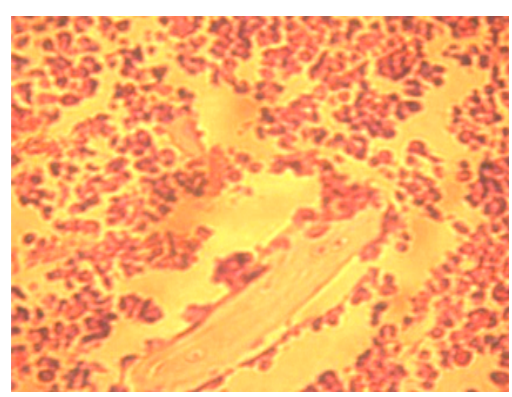

Haematoxilin \& Eosin $\times 1000$

Figure 2. Showing sections of bone marrow biopsy with normal architecture separated into sinusoids with red/white cells at various stages of development. A few fat cells surrounded by osteoblast/matured bones are present

GROUP B (200ml/kg)

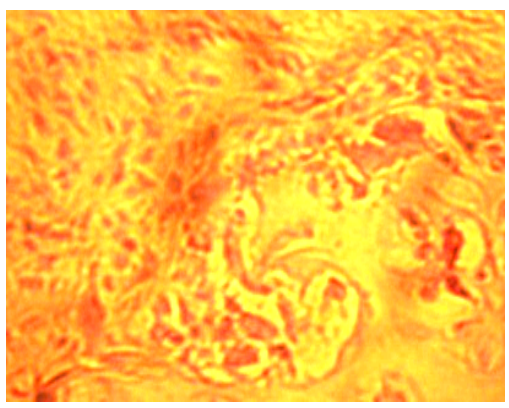

$\mathrm{H} \& \mathrm{E} \times 1000$

Figure 3. showing bone marrow biopsy with sinusoids containing few blood cells separated by loose connective tissue. The surrounding bone is composed of osteoblast and osteon lined by a thin rim of endothelium

GROUP C $(300 \mathrm{ml} / \mathrm{kg})$

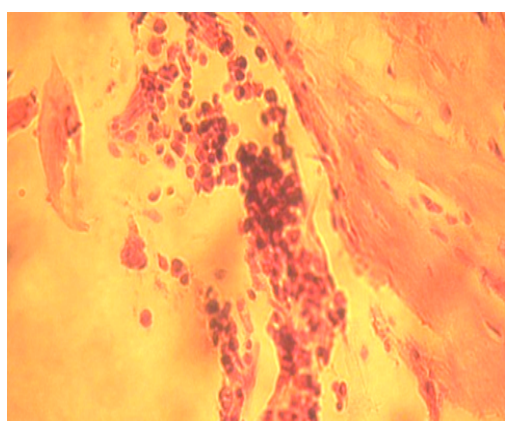

$\mathrm{H} \& \mathrm{E} \times 1000$

Figure 4. showing sections of bone marrow with distorted marrow architecture of few sinusoids in which are scant matured forms of red/white blood cells. Few megakaryocytes and matured red/white cells are also seen 
GROUP D $(500 \mathrm{ml} / \mathrm{kg})$

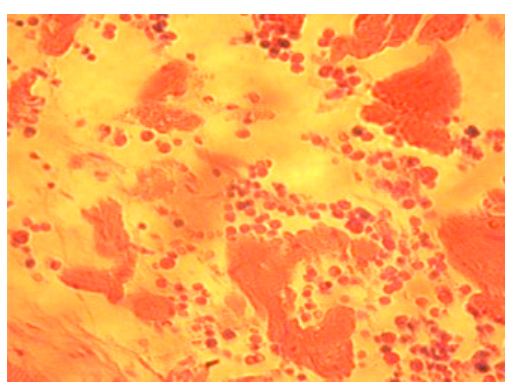

$\mathrm{H} \& \mathrm{E} \times 1000$

Figure 5. Sections of bone marrow show markedly attenuated marrow architecture with scant sinusoids in which are few blood cells

\section{Discussion}

In this study, oral administration of alcoholic extract of Cnidoscolus aconitifolius for a period of two weeks showed a significant increase in the weights of the tested rats. This finding may be due to an increase in weight could be as a result of odema due to the destructive effect of the extract on the body tissues by its constituent (Kolterman et al., 1984). It may also indicate the possible nutritive value of the plant as observed by (Munsel et al., 1949; Kuti et al., 2004; Martin and Ruberte, 1978).

Observations from the bone marrow biopsy, showed a significant decrease in distortion of bone marrow architecture. Rats in group B had a lesser destructive effect compared to rats in group $\mathrm{C}$ and $\mathrm{D}$ which showed maximum destruction. This observed effect could be as a result of hydrocyanide (Kolterman et al., 1984).

It is likely that some of the phytochemical constituents of the plant may have a destructive effect on bone marrow even at the lowest concentration. This observation may be as a result of the Tannin and Phenol content (Okwu, 2004). Other phytochemical substances which may cause bone marrow toxicity include flavonoid (Florence et al., 2009). Flavonoids have been said to contain Kaempferol and Quercetin glycosides (Kolterman et al., 1984).

\section{Conclusions}

Consumption of $\mathrm{C}$. aconitifolius causes bone marrow destruction in a dose dependent pattern.

\section{REFERENCES}

[1] Awoyonka, A. O., Balogun, I. O. and Ogunnowo, A. A. (2007). Phytohemical screening and invitro bioactivity of
Cnidoscolus aconitifolius (Euphorbiaceae). J. med. Plant res., 3 , pp. $63-65$.

[2] Barbara, Y., James, S. L., Alan, S. and John, W. H. (2006). Wheaters functional histology. Churchill livingstone, china. 5th edition, 3 , pp. $46-59$.

[3] Barker, N. S., Zahurak, M. Olson, J. L, Nadasdy, T., Rascusen, L. C. and Hruban, R. H. (1998). Digital imaging of black and White Photomicrographs Impact of file size. Am. J. Surg. Pathol., 22(11), 1411 - 6.

[4] Diaz - bolio, J. (1975). Chaya (Cnidoscolus chayamansa, Euphorbiaceae), A marvelous food (in spinach). Tierra, 30, pp. $407-408$.

[5] De buryn, P. P. H. (1981). Structural substrates of bone marrow fuctionSemin Hematol., 18, pp. 179 - 193.

[6] Drury, R. A. B., Wallington, E. A. and Cameron R. (1967). Carletons histological technique.

[7] Iwalewa, E. O., Adewunmi C. O., Omisore N. O. and Adebanji O. A. (2005). Pro - anti oxidant effect of vegetables in south west Nigeria. J. med. Food, 8, pp 531 - 534.

[8] Kolterman, D. A., Breckon, G. J. and Kowal, R. R. (1984). Chemotaxonomic studies in Cnidoscolus, flavonoids of $\mathrm{C}$. aconitifolius, C. souzae an C. spinosus. Systematic botany, $9(1)$, pp. $22-32$.

[9] Krause, J. R. (1981). Bone marrow biopsy. Edinburgh. Churchill Livingstone.

[10] Kuti, J. O., Elise, S. T. and Jarnick, J. (1996). Potential nutrition and health benefits of tree spinach progress in new crops, pp. $516-520$.

[11] Kuti, J. O. and Konuru, H. B. (2004). Anti oxidant capacity and phenolic content in leaf extracts of tree spinach (Cnidoscolus spp.). journal of agricultural and food chemistry, 52 pp. 117.

[12] Martin , F. W. and Ruberte, R. (1978). Cnidoscolus chayamansa includes composition and nutritional value, culture in Puerto Rico; vegetables of hot humid tropics. USDA, ARS. New Orleans.

[13] Munsell, H. E., Williams, L. O., Guild, L. P., Troescher, C. B., Nightingale, G. and Harris, R. S. (1949). Composition of food plants of central America. Food Res., 14, pp. 144 - 164.

[14] Okwu D. E.and Josiah C. (2006) Evaluation of the chemical composition of two Nigerian

[15] medicinal plantsAfrican Journal of Biotechnology Vol. 5 (4), pp. 357-361

[16] Oyagbemi, A. A., Odetola, A. A. and Azeez, O. I. (2008). Ameliorative effects of Cnidoscolus aconitifolius on anaemia and osmotic fragility induced by protein energy malnutrition. Journal of biotech., vol. 7(11), pp. 1721 - 1726.

[17] Rowe, L. (1994). Plant guards secret of good health, valley morning star. pp. A1 - A12. 